Research Article

\title{
Accuracy of Intraoperative Frozen Section in Diagnosing Malignancy of Ovarian Neoplasm
}

\author{
Akurasi Pemeriksaan Potong Beku Intra-Operatif dalam \\ Mendiagnosa Keganasan Neoplasma Ovarium
}

\author{
Tofan W Utami, Jasmine Iskandar, Gregorius Tanamas, Mona Jamtani, \\ Laila Nuranna, Kartiwa H Nuryanto \\ Division of Gynecologic Oncology \\ Department of Obstetrics and Gynecology \\ Faculty of Medicine University of Indonesial \\ Dr. Cipto Mangunkusumo Hospital \\ Jakarta
}

\begin{abstract}
Objective: To evaluate the accuracy of frozen section for ovarian neoplasm in our hospital.

Method: A retrospective evaluation was conducted on medical records of patients with ovarian neoplasms who underwent a frozen section laparotomy between the years 2008 and 2013 at Dr. Cipto Mangunkusumo Hospital. Records with incomplete data on frozen section or paraffin block report were excluded. Criteria for frozen section laparotomy in our facility was based on a malignancy score of equal to or more than 6 . Frozen section reports were compared to paraffin block report based on benign, borderline, or malignant cases.

Result: From 139 patients with ovarian neoplasm, only 91 patients fulfilled the inclusion and exclusion criteria. Frozen section examination revealed benign cases was $15.4 \%$, borderline cases was $15.4 \%$, and malignant cases was $69.2 \%$. Based on histopathological type, clear cell cystoadenocarcinoma was the most commonly observed histotype $(19.8 \%)$. The sensitivity of frozen section for benign, borderline, and malignancy cases respectively was $81.8 \%, 76.9 \%, 91.0 \%$. The specificity of frozen section for benign, borderline, and malignancy case respectively was $93.8 \%, 94.8 \%, 91.6 \%$.

Conclusion: We found that the accuracy of intraoperative frozen section in our facility is adequate to diagnose ovarian neoplasm and can be used to assist in determining the extent of surgical management. [Indones J Obstet Gynecol 2015; 3: 161-164]
\end{abstract}

Keywords: frozen section, ovarian neoplasm, paraffin block, sensitivity, specitificity

\section{Abstrak}

Tujuan: Mengetahui akurasi pemeriksaan potong beku pada kasus tumor ovarium di rumah sakit kami.

Metode: Penelitian ini menggunakan desain retrospektif berdasarkan rekam medis pasien dengan tumor ovarium yang dilakukan prosedur laparotomi dengan pemeriksaan potong beku pada tabun 2008-2013 di Rumah Sakit Dr. Cipto Mangunkusumo. Rekam medis dengan laporan potong beku atau blok paraffin yang tidak lengkap dieksklusi dari penelitian. Kriteria untuk dilakukan potong beku pada pasien di rumah sakit kami menggunakan skor keganasan sama atau lebib dari 6. Laporan pemeriksaan potong beku dibandingkan dengan pemeriksaan blok paraffin dengan kesimpulan kasus jinak, borderline, atan ganas.

Hasil: Dari 139 pasien dengan tumor ovarium, hanya 91 pasien yang memenubi kriteria inklusi dan eksklusi. Berdasarkan laporan potong beku didapatkan 15,4\% kasus jinak, 15,4\% kasus borderline, dan 69,8\% kasus ganas. Sensitivitas dari potong beku untuk kasus jinak, borderline, dan ganas secara berturut-turut adalab 81,8\%,76,9\%,91,0\%. Spesifisitas dari potong beku untuk kasus jinak, borderline, dan ganas secara berturut-turut adalah 93,8\%, 94,8\%, 91,6\%.

Kesimpulan: Akurasi dari pemeriksaan potong beku intra-operasi di rumah sakit kami cukup baik untuk mendiagnosa keganasan ovarium dan dapat digunakan sebagai pertimbangan mengambil keputusan dalam manajemen selanjutnya.

[Maj Obstet Ginekol Indones 2015; 3: 161-164]

Kata kunci: blok paraffin, potong beku, sensitivitas, spesifisitas, tumor ovarium

Correspondence: Tofan W Utami. Department of Obstetrics and Gynecology, Faculty of Medicine University of Indonesia/ Dr. Cipto Mangunkusumo, Jakarta. Telephone: 021-3914806, tofanwidya@yahoo.com

\section{INTRODUCTION}

Ovarian cancer represents the fifth most commonly diagnosed cancer among women in the world, and causes more deaths per year than any other female gynecologic malignancy. ${ }^{1,2}$ There are three forms of epithelial ovarian neoplasm, namely benign, borderline, and malignant. ${ }^{3}$ Based on histological type, type
I is composed of low-grade serous, low-grade endometrioid, clear cell, mucinous and transitional (Brenner) carcinomas. These tumors generally behave in an indolent fashion, are confined to the ovary at presentation and, as a group, are relatively genetically stable. Another group of tumors, type II include conventional high-grade serous carcinoma, undifferentiated carcinoma, and malignant 
mixed mesodermal tumors (carcinosarcoma) and this tumor is highly aggressive, evolves rapidly and almost always presents in advanced stage. ${ }^{4,5}$

Preoperative discrimination of adnexal mass can be made with Risk of Malignancy Index (RMI) or using a malignancy score in our center. ${ }^{6-8}$ Intraoperative diagnosis is conducted through frozen section by evaluating the histological type of the mass., ${ }^{2,7}, 8$ Frozen section is performed by freezing the tissue portion in a cryostat machine and then being stained. ${ }^{9}$ Frozen section allows surgeons to decide whether to perform extensive resection or not. ${ }^{8,9}$ However, more accurate diagnosis of histological type and degree is achieved by using paraffin block. $2,3,8$

Many studies have confirmed the accuracy of frozen section diagnosis for assessment of ovarian neoplasms with acceptable sensitivity $(71-97 \%)$ and specificity of more than $95 \% .^{10-14}$ The limitations of frozen section procedure are mostly for borderline, mucinous and large tumors. Frozen section is most reliable for small serous tumors. ${ }^{10,15,16}$ Several factors can affect the accuracy of frozen section diagnosis, such as patient characteristics, tumor size, histological type, and the pathologist's experience. ${ }^{10,15}$ Histological typing of ovarian neoplasm followed the International Federation of Gynecology and Obstetrics (FIGO) recommendations. ${ }^{17}$ The accuracy of frozen section for ovarian neoplasm has not been reported yet in our hospital, so we would like to evaluate the accuracy of frozen section for ovarian neoplasm in our hospital.

\section{METHODS}

A retrospective evaluation was conducted on medical records of patients with ovarian neoplasms who underwent a frozen section laparotomy between the years 2008-2013 at Dr. Cipto Mangunkusumo Hospital. Records with incomplete data on frozen section or paraffin block report were excluded. Criteria for frozen section laparotomy in our facility was based on a Malignancy score of equal to or more than 6 . The malignancy score is made up of five parameters; $10 \%$ drop in body weight over the last 3 months, ascites, resistive index (RI) less than 0.4 on ultrasound, solid mass on ultrasound, and CA125 level of over 135. Each, if present, gets a score of 2 . A score $\geq 6$ indicates suspicion for malignancy. ${ }^{6}$
For histologic examinations, once tumor is removed, 2-5 tissue samples are taken from parts of the mass that appear irregular. Frozen sections are immediately studied and reported. Paraffin block examinations are conducted according to the standard. Histology reports that were recorded were classified into benign, borderline and malignant. Results of the frozen section were then compared to results from the paraffin block. Paraffin block is more accurate for histological type and grade compared to frozen section. For the purpose of this study, the final histopathological diagnose was assumed to be correct.

Descriptive statistics were obtained and sensitivity, specificity, positive predictive value (PPV) and negative predictive value (NPV) were calculated.

\section{RESULTS}

We found a total of 139 records of patients who underwent laparotomy for presumed malignant ovarian neoplasm in the years 2008-2013. In 37 cases, frozen section was not done, and in 11 , paraffin block results were not available. Ninety-one cases were analyzed. The mean age was 45.02 \pm 10.8 , with the youngest being 18 years old and the oldest 65 years old. The final histopathologic report is described in Table 1.

Final histopathology results showed 11 patients with no malignancy, 14 patients with borderline tumor and 48 patients with cystoadenocarcinoma.

The frozen section results were $14(15.4 \%)$ benign, $14(15.4 \%)$ borderline and $63(69.3 \%)$ malignant. The final histopathologic diagnosis comprised of $11(12.1 \%)$ benign, $13(14.3 \%)$ borderline, and $67(73.7 \%)$ malignant cases. The overall accuracy of frozen section diagnosis was $87.9 \%$, calculated from the total cases correctly diagnosed over the total number of cases. The paraffin result was worse than the frozen section result in $8.7 \%$ and better in $3.2 \%$ of cases.

The sensitivity, specificity, PPV and NPV were analyzed (Table 3 ). The sensitivity of frozen section diagnosis is $81.8 \%$ for benign, $76.9 \%$ for borderline, and $91.0 \%$ for malignant. Specificity value for benign, borderline and malignant tumors were $93.8 \%$, $94.8 \%$, and $91.6 \%$, respectively.

The results were later analyzed for area under the ROC curve, which proved that frozen sections are useful in diagnosing malignancies (AUC >0.8). 
Table 1. Final Histopathology Report.

\begin{tabular}{|c|c|c|}
\hline Histotype & Frequency & Percent $(\%)$ \\
\hline Non Malignancy & 11 & 12.1 \\
\hline Serous Cystoadenoma Borderline & 5 & 5.5 \\
\hline Mucinous Cystoadenoma Borderline & 7 & 7.7 \\
\hline Endometrioid Cystoadenoma Borderline & 1 & 1.1 \\
\hline Clear Cell Cystoadenoma Borderline & 1 & 1.1 \\
\hline Serous Cystoadenocarcinoma & 11 & 12.1 \\
\hline Mucinous Cystoadenocarcinoma & 9 & 9.9 \\
\hline Endometrioid Cystoadenocarcinoma & 10 & 11.0 \\
\hline Clear Cell Cystoadenocarcinoma & 18 & 19.8 \\
\hline Adenofibroma Cyst & 1 & 1.1 \\
\hline Granulosa Cell Tumor & 5 & 5.5 \\
\hline Endodermal sinus (yolk sac) tumor & 3 & 3.3 \\
\hline Ovarian Fibroma & 1 & 1.1 \\
\hline Dysgerminoma & 3 & 3.3 \\
\hline Immature Teratoma & 5 & 5.5 \\
\hline Total & 91 & 100,1 \\
\hline
\end{tabular}

Table 2. The Results of Frozen Section and Paraffin Sections in Various Categories of Ovarian Neoplasms ( $\mathrm{n}=91)$

\begin{tabular}{llcccc}
\hline \hline & & \multicolumn{3}{c}{ Paraffin } \\
\cline { 3 - 6 } & & Benign & Borderline & Malignant & Total \\
\hline \multirow{3}{*}{ Frozen } & Benign & 9 & 2 & 3 & 14 \\
Section & Borderline & 1 & 10 & 3 & 14 \\
& Malignant & 1 & 1 & 61 & 63 \\
& Total & 11 & 13 & 67 & 91 \\
\hline \hline
\end{tabular}

Table 3. Sensitivity, Specificity, PPV and NPV of Frozen Sections (\%)

\begin{tabular}{cccccc}
\hline \hline & Sensitivity (\%) & Specificity (\%) & PPV (\%) & NPV (\%) & AUC \\
\hline Benign & 81.8 & 93.8 & 64.2 & 97.5 & 0.87 \\
Borderline & 76.9 & 94.8 & 66.6 & 96.1 & 0.85 \\
Malignant & 91.0 & 91.6 & 96.8 & 78.5 & 0.91 \\
\hline \hline
\end{tabular}

\section{DISCUSSION}

Intraoperative frozen section has been used to diagnose ovarian neoplasm for a considerable time. Intraoperative diagnosis can dictate the extent of surgery; therefore its accuracy is very important. Many studies have confirmed the accuracy of frozen section diagnosis for the assessment of ovarian neoplasms with acceptable sensitivity (71-97\%) and specificity of more than $95 \% .{ }^{10-14}$ Various studies have shown that the overall accuracy of frozen sections range from $86 \%-97 \% .^{3,7}$ In this study, we found that the overall accuracy of intraoperative frozen section in our facility was adequate, at $87.9 \%$.

The procedure fared well in terms of sensitivity, specificity, PPV and NPV. A meta analysis found that sensitivity of frozen section for benign and ma- 
lignant lesions are $65-97 \%$ and $71-100 \%$ respectively, and specificity are $97-100 \%$ and $98.3-100 \%$ respectively. $2,3,7$ In our study, we found that sensitivity for benign and malignant lesions to be $81.8 \%$ and $91.0 \%$, respectively. However, specificity was lower at $91.0 \%$ and $91.66 \%$ for benign and malignant lesions, respectively.

This test proved to be great for detecting malignant lesion (AUC 0.9). However, PPV for benign tumors was low at $64.3 \%$, indicating that there was a 1 in 3 possibility that a frozen section diagnosis of benign lesion will return with a borderline or malignant histopathology. In this study, 14.2\% $(n=2)$ benign diagnosis from frozen section was found to be borderline and $21.4 \%(n=3)$ found to be malignant. This was correlated to the relatively low NPV for malignant diagnosis. On the other hand, over-diagnosis of benign cases as borderline and malignant was $0.9 \%(n=1)$ each. This may be due to the low number of benign cases, as predictive values are related to prevalence. It is further precipitated by the fact that frozen sections are generally done when there is preoperative suspicion of malignancy. Until proven, however, the concern for underdiagnosis must be implied in practice and patients with benign frozen section results must be followed up until their final diagnosis is established.

Consistent with other studies, frozen section shows the lowest sensitivity for borderline tumors. ${ }^{2-4}$ In this study, the sensitivity and specificity are $76.9 \%$ and $94.8 \%$, respectively. Of 14 borderline frozen section results, three were later diagnosed as malignant, and one as benign. There is a recurring trend for underdiagnosis, which may be attributable to low prevalence of borderline cases. On the other hand overdiagnosis was rare, with one case $(9.0 \%)$ of benign tumor detected as borderline and malignant each, and one case $(7.6 \%)$ of borderline tumor detected as malignant.

\section{CONCLUSION}

In conclusion, we found that the accuracy of intraoperative frozen section in our facility is adequate to diagnose ovarian neoplasm, and can be used to assist in determining the extent of surgical management. Further research with a larger sample and comparing patient characteristics to the accuracy of frozen section is needed to increase the understanding of factors affecting frozen section accuracy.

\section{REFERENCES}

1. Permuth-Wey J, Sellers TA. Epidemiology of ovarian cancer. Methods Mol Biol 2009; 472: 413-37.

2. Yarandi F, Eftekhar Z, Izadi-Mood N, et al. Accuracy of intraoperative frozen section in the diagnosis of ovarian tumors. Aus New Zealand J Obstet Gynecol 2008; 48: 438-41.

3. Maheshwari A, Gupta S, Kane S, et al. Accuracy of intraoperative frozen section in the diagnosis of ovarian neoplasms: Experience at a tertiary oncology center. World J Sur Oncol 2006; 4: 12.

4. Kurman RJ, Shih Ie M. The origin and pathogenesis of epithelial ovarian cancer: a proposed unifying theory. Am J Sur Pathol 2010; 34(3): 433-43.

5. Cunningham JM, Cicek MS, Larson NB, et al. Clinical characteristics of ovarian cancer classified by BRCA1, BRCA2, and RAD51C status. Sci Rep 2014; 4.

6. INASGO. Pedoman Pelayanan Medik Kanker Ginekologi. $2^{\text {nd }}$ ed. Jakarta: Badan Penerbit FKUI; 2011.

7. Ilker A, Aykut B, Muge H, et al. Accuracy of intra-operative frozen section in the diagnosis of ovarian tumours. J Pak Med Assoc 2011; 61(9): 856-8.

8. Wootipoom V, Dechsukhum C, Hanprasertpong J, et al. Accuracy of intraoperative frozen section in diagnosis of ovarian tumors. J Med Assoc Thai 2006; 89(5): 577-82.

9. Brender E, Burke A, Glass RM. Frozen section biopsy. JAMA 2005; 294(24): 3200.

10. Brun JL, Cortez A, Rouzier R, et al. Factors influencing the use and accuracy of frozen section diagnosis of epithelial ovarian tumors. Am J Obstet Gynecol 2008; 199(3): 244 e1-7.

11. Shih KK, Garg K, Soslow RA, et al. Accuracy of frozen section diagnosis of ovarian borderline tumor. Gynecol Oncol 2011; 123(3): 517-21.

12. Geomini P, Bremer G, Kruitwagen R, et al. Diagnostic accuracy of frozen section diagnosis of the adnexal mass: a metaanalysis. Gynecol Oncol 2005; 96(1): 1-9.

13. Moszynski R, Szpurek D, Smolen A, et al. Comparison of diagnostic usefulness of predictive models in preliminary differentiation of adnexal masses. Int J Gynecol Cancer 2006; 16(1): 45-51.

14. Wakahara F, Kikkawa F, Nawa A, et al. Diagnostic efficacy of tumor markers, sonography, and intraoperative frozen section for ovarian tumors. Gynecol Obstet Invest $2001 ; 52(3):$ 147-52.

15. Subbian A, Devi UK, Bafna UD. Accuracy rate of frozen section studies in ovarian cancers: A regional cancer institute experience. Ind J Cancer 2013; 50(4): 302-5.

16. Bige O, Demir A, Saygili U, et al. Frozen section diagnoses of 578 ovarian tumors made by pathologists with and without expertise on gynecologic pathology. Gynecol Oncol 2011; 123(1): 43-6.

17. Benedet JL, Bender H, Jones H, $3^{\text {rd }}$, et al. FIGO staging classifications and clinical practice guidelines in the management of gynecologic cancers. FIGO Committee on Gynecologic Oncology: the official organ of the International Federation of Gynaecology and Obstetrics. Int J Gynecol Obstet 2000; 70(2): 209-62. 